\title{
No association evidence between schizophrenia and dystrobrevin-binding protein 1 (DTNBP1) in Taiwanese families
}

\author{
Chih-Min Liu ${ }^{\mathrm{a}, \mathrm{b}}$, Yu-Li Liu ${ }^{\mathrm{c}}$, Cathy Shen-Jang Fann ${ }^{\mathrm{d}}$, Wei-Chih Yang ${ }^{\mathrm{d}}$, \\ Jer-Yuarn $\mathrm{Wu}^{\mathrm{e}}$, Shuen-Iu Hung ${ }^{\mathrm{e}}$, Wei J. Chen ${ }^{\mathrm{f}}$, Ching-Mo Chueh ${ }^{\mathrm{g}}$, Wei-Ming Liu ${ }^{\mathrm{h}}$, \\ Chen-Chung Liu ${ }^{a}$, Ming-Hsien Hsieh ${ }^{\text {a }}$, Tzung-Jeng Hwang ${ }^{a}$, Stephen V. Faraone ${ }^{\mathrm{i}}$, \\ Ming T. Tsuang ${ }^{\mathrm{j}}$, Hai-Gwo Hwu ${ }^{\mathrm{a}, \mathrm{f}, *}$ \\ a Department of Psychiatry, National Taiwan University Hospital and National Taiwan University College of Medicine, Taipei, Taiwan \\ ${ }^{\mathrm{b}}$ Graduate Institute of Clinical Medicine, National Taiwan University College of Medicine, Taipei, Taiwan \\ ${ }^{\mathrm{c}}$ Division of Mental Health and Substance Abuse Research, National Health Research Institutes, Taipei, Taiwan \\ ${ }^{\mathrm{d}}$ Institute of Biomedical Science, Academia Sinica, Taipei, Taiwan \\ e National Genotyping Center, Institute of Biomedical Science, Academia Sinica, Taipei, Taiwan \\ ${ }^{\mathrm{f}}$ Institute of Epidemiology, College of Public Health, National Taiwan University, Taipei, Taiwan \\ g Department of Psychiatry, Kaohsiung Veterans General Hospital, Kaohsiung, Taiwan \\ ${ }^{\mathrm{h}}$ Yuli Hospital, Department of Health, Executive Yuan, Hualien, Taiwan \\ ${ }^{\mathrm{i}}$ Medical Genetics Research Center and Departments of Psychiatry and Neuroscience and Physiology, SUNY Upstate Medical University, \\ Syracuse, New York, USA \\ ${ }^{\mathrm{j}}$ Institute of Behavioral Genomics University of California, San Diego, California, and Harvard Institute of Psychiatric Epidemiology and \\ Genetics, Boston, Massachusetts, USA
}

Received 3 July 2006; received in revised form 6 February 2007; accepted 9 February 2007

Available online 3 April 2007

\begin{abstract}
Several linkage studies have shown significant linkage of schizophrenia to chromosome $6 \mathrm{p}$ region, which includes the positional candidate genes, Dystrobrevin-binding protein 1 (DTNBP1). The aim was to examine the association evidence of the candidate gene in 693 Taiwanese families with at least two affected siblings of schizophrenia. We genotyped nine SNPs of this gene with average intermarker distance of $17 \mathrm{~kb}$. Intermarker linkage disequilibrium was calculated with GOLD. Single locus and haplotype association analyses were performed with TRANSMIT program. We found no significant association between schizophrenia and DTNBP1 either through single locus or haplotype analyses. We failed to replicate the association evidence between DTNBP1 and schizophrenia and this gene may not play a major role in the etiology of schizophrenia in this Taiwanese family sample.
\end{abstract}

(C) 2007 Elsevier B.V. All rights reserved.

Keywords: Schizophrenia; DTNBP1; Chromosome 6p; Family-based association study

* Corresponding author. Department of Psychiatry, National Taiwan University Hospital, No. 7 Chung San South Road, Taipei, 100, Taiwan. Tel.: +886 22312 3456x6657; fax: +8862 23314775 .

E-mail address: haigohwu@ntu.edu.tw (H.-G. Hwu).

\section{Introduction}

Schizophrenia is a serious mental illness affecting $1 \%$ of the general population. Family, twin, and adoption 
studies have shown that schizophrenia is predominantly genetically determined and has high heritability (McGuffin et al., 2003). A multilocus model is favored and assumes that there are several genes, each having a small effect and acting in epistasis, responsible for schizophrenia (Risch, 1990). Using linkage analyses, a number of positive findings have been reported on chromosome 6p (Antonarakis et al., 1995; Arolt et al., 1996; Bailer et al., 2000; Brzustowicz et al., 1997; Matthysse et al., 2004; Maziade et al., 2001; Moises et al., 1995; Schwab et al., 1995, 2000; Straub et al., 2002b, 1995, 1996; Wang et al., 1995). Furthermore, suggestive linkage evidence for chromosome $6 p$ was reported in our earlier report using Taiwanese family sample (Hwu et al., 2000).

There have been several reports implicating DTNBP1 in the etiology of schizophrenia. Straub et al. (2002a) presented the original evidence for a significant association between schizophrenia and SNPs within DTNBP1 in a sample of 270 multiply affected Irish pedigrees. In that study, eight SNPs across the gene, as well as several three-marker haplotypes, showed significant over-transmission to affected offspring across a range of different diagnostic categories. Significant genetic association evidence has also been produced by several investigations of various ethnic samples using different study designs (Fallin et al., 2005; Funke et al., 2004; Gornick et al., 2005; Kirov et al., 2004; Li et al., 2005; Numakawa et al., 2004; Schwab et al., 2003; Tang et al., 2003; Tochigi et al., 2006; van den Oord et al., 2003; Williams et al., 2004), however, several others have failed to replicate the result (De Luca et al., 2005; Hall et al., 2004; Holliday et al., 2006; Joo et al., 2006; Morris et al., 2003). It has also been reported that the gene is significantly associated with schizophrenic patients with positive family history (Van Den Bogaert et al., 2003), and associated with patients with high levels of negative symptoms (DeRosse et al., 2006; Fanous et al., 2005).

DTNBP1 shows widespread expression in the human brain (Weickert et al., 2004). Talbot et al. (2004) found that the level of presynaptic dysbindin-1 are reduced in schizophrenia and are related to glutamatergic alterations in intrinsic hippocampal formation connections. Numakawa et al. (2004) found that, in neuronal culture, over-expression of dysbindin induced expression of SNAP25 and synapsin-I, promoted phosphorylation of Akt and increased glutamate release. Conversely, knockdown of dysbindin expression resulted in lower pre-synaptic protein expression and a decrease in glutamate release (Numakawa et al., 2004). Bray et al. (2005) showed that a defined schizophrenia risk haplotype tags one or more cis-acting variants that results in a relative reduction in DTNBP1 mRNA expression in human cerebral cortex, indicating variation in the DTNBP1 gene confers susceptibility to schizophrenia through reduced expression.

Our aim here was to examine the association evidence between schizophrenia and DTNBP1 in a large family sample of 693 Taiwanese families with at least two siblings affected with schizophrenia.

\section{Materials and methods}

\subsection{Subjects}

The subjects were recruited from two sample collection programs; the Multi-dimensional Psychopathology Study of Schizophrenia (MPSS) from 1993 to 2001 (Hwu et al., 2002) and the Taiwan Schizophrenia Linkage Study (TSLS) (Hwu et al., 2005) from 1998 to 2002. A total of 693 families with at least two affected siblings with schizophrenia were used for this study, of which 86 families were from MPSS and 607 were from TSLS.

The MPSS families were recruited mainly from the Department of Psychiatry, National Taiwan University Hospital and the University-affiliated Taoyuan Psychiatric Center. The families came mostly from northern Taiwan. Data collection was initiated after informed consent had been obtained from the identified study subjects and their families. All family members were personally interviewed by research psychiatrists using the Psychiatrist Diagnostic Assessment (PDA) (Hwu, 1999). The final diagnostic assessment was formulated by integrating the PDA data and clinical information obtained from the medical chart records. The final diagnosis used criteria specified by the Diagnostic and Statistical Manual of Mental Disorders fourth edition (DSM-IV) (APA, 1994).

The TSLS families were recruited from hospitals all over Taiwan, except for the above two institutions. Data collection was initiated after informed consent had been obtained from the identified study subjects and their family members. All the family members were interviewed by well-trained assistants using the Mandarin Chinese version of the Diagnostic Interview for Genetic Studies (DIGS) (Chen et al., 1998). The final diagnostic assessment was formulated by integration of the DIGS data and clinical information from the medical chart records by two board-certified research psychiatrists independently. Research diagnosis was made based on DSM-IV criteria. All data schedules and medical records for subjects with inconsistent diagnoses from 
these two independent research diagnosticians were evaluated further by the senior researcher (H-G Hwu) to achieve final diagnosis. Detailed information has been previously published about the recruitment procedures (Hwu et al., 2005). Both projects of sample recruitment have been approved by the ethics committee of National Taiwan University Hospital.

The diagnoses were comparable between the two sample collection programs, because they were both made based on DSM-IV criteria. Clinical symptoms were rated using schedule for assessment of negative symptoms (SANS) (Andreasen, 1983) and schedule for assessment of positive symptoms (SAPS) (Andreasen, 1984) with satisfactory reliability. The comparison of age at onset between the affected individuals of the two samples was not significant. The severity of positive and negative symptoms were comparable and the severity of positive symptoms are with low mean values of 1.31 and 1.63 for MPSS and TSLS sample, respectively, and the severity of negative symptoms are of 1.92 and 1.65 for MPSS and TSLS sample, respectively. Under the sensitive statistical method of generalized estimating equations (GEE) model, for related affected sibpairs, with large sample size, the positive symptoms of TSLS sample were significantly more severe than those of MPSS sample. On the contrary, the negative symptoms of TSLS sample were significantly less severe than those of MPSS sample. We judged that the small differences, though significant, of clinical symptoms between the two samples would contribute little to subsequent genetic analyses.

Through the procedures described above and elsewhere, we enrolled a total of 693 multiplex (i.e. at least two affected siblings) schizophrenic nuclear families, incorporating a total of 2787 individuals from whom DNA was available. This sample is a representative family sample, which includes about $40 \%$ of all multiplex schizophrenic families in Taiwan (Hwu et al., 2005). The family structure detailed by the number of affected offspring and parent genotyped is presented in Table 1. A total of 1487 individuals were

Table 1

Distribution of families by number of affected offspring and parents genotyped

\begin{tabular}{lrrrr}
\hline $\begin{array}{l}\text { Affected offspring } \\
\text { genotyped }\end{array}$ & \multicolumn{3}{c}{ Parents genotyped } & Total \\
\cline { 2 - 4 } & \multicolumn{1}{c}{0} & \multicolumn{1}{c}{2} & \\
\hline 1 & 3 & 5 & 5 & 13 \\
2 & 22 & 283 & 325 & 630 \\
3 & 2 & 36 & 10 & 48 \\
4 & 0 & 2 & 0 & 2 \\
Total & 27 & 326 & 340 & 693 \\
\hline
\end{tabular}

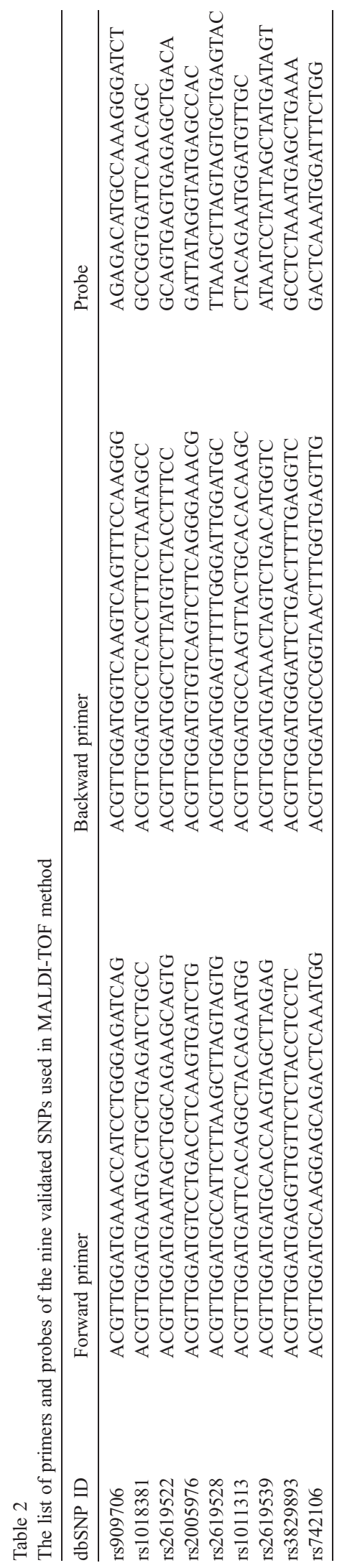


Table 3

Detailed description of the validated SNPs for DTNBP1 and the single locus association analysis results

\begin{tabular}{|c|c|c|c|c|c|c|}
\hline \multirow{2}{*}{$\begin{array}{l}\text { dbSNP ID. } \\
{\text { (alternative SNP name })^{a}}^{a}\end{array}$} & \multirow[t]{2}{*}{ Location $^{b}$} & \multirow{2}{*}{$\begin{array}{l}\text { Intermarker } \\
\text { distance }(\mathrm{kb})\end{array}$} & \multirow[t]{2}{*}{ Polymorphism $^{c}$} & \multirow{2}{*}{$\begin{array}{l}\text { Minor allele } \\
\text { frequency }\end{array}$} & \multicolumn{2}{|c|}{ Single locus association } \\
\hline & & & & & Chi-square & $p$-value \\
\hline rs909706 (P1583) & Intron 1 & - & $\mathrm{T} / \mathrm{C}$ & 0.40 & 0.13 & 0.71 \\
\hline rs1018381 (P1578) & Intron 1 & 3.8 & $\mathrm{C} / \mathrm{T}$ & 0.07 & 0.33 & 0.56 \\
\hline rs2619522 (P1763) & Intron 1 & 3.4 & $\mathrm{~A} / \mathrm{C}$ & 0.08 & 0.11 & 0.74 \\
\hline rs2005976 (P1757) & Intron 3 & 2.8 & $\mathrm{G} / \mathrm{A}$ & 0.08 & 0.11 & 0.74 \\
\hline rs2619528 (P1765) & Intron 3 & 1.0 & $\mathrm{G} / \mathrm{A}$ & 0.08 & 0.10 & 0.75 \\
\hline rs1011313 (P1325) & Intron 4 & 16.4 & $\mathrm{C} / \mathrm{T}$ & 0.19 & 3.09 & 0.079 \\
\hline rs2619539 (P1655) & Intron 5 & 12.6 & $\mathrm{C} / \mathrm{G}$ & 0.39 & 0.20 & 0.66 \\
\hline rs3829893 & Intron 5 & 5.2 & $\mathrm{G} / \mathrm{A}$ & 0.32 & 0.10 & 0.76 \\
\hline rs742106 (P1328) & Intron 9 & 91.2 & $\mathrm{~T} / \mathrm{C}$ & 0.42 & 0.63 & 0.43 \\
\hline
\end{tabular}

a The SNP number in the study of Straub et al. (2002a).

b The SNP location for DTNBP1 was determined based upon the m-RNA accession no. NM_032122.

c Second allele under oblique line (/) is the minor allele.

diagnosed schizophrenic; the mean age was 36.0 $( \pm 9.6)$ years and $61.1 \%$ were male. The mean age at onset was $22.9( \pm 6.8)$ years. The mean age of the unaffected subjects was $55.7( \pm 15.4)$ years with $48.4 \%$ male.

\subsection{SNP selection and validation}

A total of 18 SNPs for DTNBP1 were selected from the previous studies (Straub et al., 2002a) and a public database (http://www.ensembl.org/Homo_sapiens/ martview) for initial validation. A sample subset of 31 trios and one independent individual was used to validate the 18 selected SNPs. Considering the power of further linkage disequilibrium test, we required SNPs to have a minor allele frequency above $10 \%$ to be genotyped in the full sample.

\subsection{SNP genotyping}

All SNP genotypings were performed by the method of matrix-assisted laser desorption/ionization-time of flight mass spectrometry (MALDI-TOF MS) (Rodi et al., 2002). Primers and probes flanking the SNPs were designed by using SpectroDESIGNER software (Sequenom, San Diego, CA, USA). A DNA fragment (100$300 \mathrm{bp}$ ) encompassing the SNP site was amplified using the four-plexed polymerase chain reaction (PCR) with GeneAmp 9700 thermocycler (Applied Biosystems, Foster city, CA, USA) under the condition of $95^{\circ} \mathrm{C}$ for $15 \mathrm{~min}$, then 45 cycles of denaturing at $95{ }^{\circ} \mathrm{C}$ for $20 \mathrm{~s}$, annealing at $56{ }^{\circ} \mathrm{C}$ for $30 \mathrm{~s}$, and extension at $72{ }^{\circ} \mathrm{C}$ for $1 \mathrm{~min}$, and finally $72{ }^{\circ} \mathrm{C}$ for $3 \mathrm{~min}$ according to the manufacturer's instruction.

To neutralize the un-incorporated deoxynunleotide triphosphate (dNTP), the PCR reaction mixture was treated with shrimp alkaline phosphatase (SAP) at $37^{\circ} \mathrm{C}$ for $20 \mathrm{~min}$. The un-incorporated dNTP was converted to deoxynucleotide diphosphate (dNDP). The reaction mixture was incubated at $85{ }^{\circ} \mathrm{C}$ for 5 min to inactivate SAP activity. Then primer extension was performed by adding the probe, Thermo Sequenase (Amersham Pharmacia, Piscataway, NJ, USA) and appropriate dideoxynucleotide triphosphate (ddNTP)/dNTP mixture, and followed by 55 cycles of denaturing at $94{ }^{\circ} \mathrm{C}$ for $5 \mathrm{~s}$, annealing at $52^{\circ} \mathrm{C}$ for $5 \mathrm{~s}$, and extension at $72{ }^{\circ} \mathrm{C}$ for

Table 4

Intermarker $D^{\prime}$ value of the nine SNPs of DTNBP1 calculated by GOLD

\begin{tabular}{|c|c|c|c|c|c|c|c|c|c|}
\hline & rs909706 & rs 1018381 & rs2619522 & rs2005976 & rs2619528 & rs1011313 & rs2619539 & rs3829893 & rs 742106 \\
\hline rs909706 & - & & & & & & & & \\
\hline rs 1018381 & .91 & - & & & & & & & \\
\hline rs2619522 & .91 & .99 & - & & & & & & \\
\hline rs 2005976 & .90 & .98 & .99 & - & & & & & \\
\hline rs2619528 & .91 & .99 & .99 & .98 & - & & & & \\
\hline rs 1011313 & .88 & .83 & .78 & .78 & .78 & - & & & \\
\hline rs 2619539 & .95 & .92 & .74 & .74 & .74 & .89 & - & & \\
\hline rs 3829893 & .93 & .84 & .83 & .81 & .81 & .87 & .92 & - & \\
\hline rs742106 & .18 & .39 & .35 & .36 & .36 & .58 & .18 & .14 & - \\
\hline
\end{tabular}


Table 5

Haplotype association analysis using TRANSMIT

\begin{tabular}{llll}
\hline $\begin{array}{l}\text { Haplotypes of } \\
\text { rs2005976-rs1011313-rs3829893 }\end{array}$ & $\begin{array}{l}\text { Haplotype } \\
\text { frequency }\end{array}$ & Chi-square & $p$-value \\
\hline G-C-G & 0.42 & 1.06 & 0.30 \\
G-C-A & 0.31 & 0.22 & 0.64 \\
G-T-G & 0.18 & 4.12 & 0.042 \\
A-C-G & 0.08 & 0.053 & 0.82 \\
\hline
\end{tabular}

$5 \mathrm{~s}$. Different extension products were differentiated by mass through MALDI-TOF. The primers of validated SNPs used for amplification and probes for extension in the MALDI-TOF method were listed in Table 2.

This genotyping method has been applied to a broad variety of clinical applications, since it fulfills criteria such as accuracy of SNP detection, sensitivity to score SNPs using a small amount of template throughput capacity, flexibility of the procedure, and cost-effectiveness (Tost and Gut, 2005).

\subsection{Statistical analysis}

We used PEDCHECK version 1.1 (O'Connell and Weeks, 1998) and UNKNOWN version 5.23 (Terwilliger and Ott, 1994) to check for Mendelian inheritance of SNPs and the Procedure ALLELE in SAS/GENETICS release 8.2 (Institute, 2002) to test for Hardy-Weinberg equilibrium. Linkage disequilibrium (LD) among markers was measured with coefficient D' (Hedrick, 1987), which was used to define haplotype blocks. A graphic presentation of block pattern was completed using GOLD software (Abecasis et al., 2000; Abecasis and Cookson, 2000). Both single point and haplotype association analyses were carried out using TRANSMIT version 2.5.4 (Clayton, 1999). SNPtagger ( $\mathrm{Ke}$ and Cardon, 2003) was used to screen for minimal sets of SNPs (haplotype tagging SNPs, htSNPs) to represent the haplotype block structure. Power estimation was calculated with PBAT (Lange et al., 2004) using the real family structure available for genotyping. The type I error was set at 0.01 . Two inherited models, additive and multiplicative, were set up with the parameters of disease gene frequency 0.05 and population prevalence 0.003 based upon previous epidemiological study (Hwu et al., 1989).

\section{Results}

At the stage of SNP validation, nine out of the eighteen SNPs, of which eight are overlapping with the SNPs studied in the initial association study (Straub et al., 2002a), with average intermarker distance of
$17 \mathrm{~kb}$ met the validation criterion of minor allele frequency above $10 \%$. Table 3 gives a detailed description of the validated SNPs.

The single SNP association analyses showed no significant evidence for any SNP of DTNBP1 (Table 3). The intermarker LD assessed by coefficient $D^{\prime}$ is presented in Table 4. The eight SNPs from rs909706 to rs3829893 showed intermarker $D^{\prime}$ above 0.7 and constituted a haplotype block. Three SNPs, rs2005916 (P1757), rs1011313 (P1325), and rs3829893, were selected as htSNPs using SNPtagger (Ke and Cardon, 2003). The haplotype association analysis using the three htSNPs showed marginally significant preferential transmission of $\mathrm{G}-\mathrm{T}-\mathrm{G}$ haplotype to affected individuals $(p=0.042)$. The detailed haplotype frequency and analysis results are shown in Table 5. We also analyzed the 2-SNP, 3-SNP haplotype associations within the 8SNP haplotype block using moving window strategy and the results were all negative (data not shown).

\section{Discussion}

This SNP fine mapping study revealed no significant association in the single locus analysis. In the haplotype association analysis, the haplotype $\mathrm{G}-\mathrm{T}-\mathrm{G}$ of the three SNPs, rs2005916 (P1757), rs1011313 (P1325), and rs3829893, had preferential transmission to affected individuals only at marginally significant level, and was not significant after correction for multiple tests. We failed to replicate the association evidence between DTNBP1 and schizophrenia in this Taiwanese family sample.

As for the negative result in our sample, we would give the following comments. Though we reported suggestive linkage evidence to 6p22.3 (Hwu et al., 2000) in a sub-sample of this study, of which 22 families

Table 6

Comparison of allele frequencies of the SNPs between our samples, those of Straub et al. (2002a) and Li et al. (2005)

\begin{tabular}{|c|c|c|c|c|}
\hline \multirow{2}{*}{$\begin{array}{l}\text { dbSNP ID. } \\
\text { (alternative } \\
\text { SNP name) }\end{array}$} & \multirow{2}{*}{$\begin{array}{l}\text { Common allele } \\
\text { (allele frequency) } \\
\text { in our samples }\end{array}$} & \multirow{2}{*}{$\begin{array}{l}\text { Straub } \\
\text { et al. } \\
(2002 a)\end{array}$} & \multicolumn{2}{|c|}{ Li et al. (2005) } \\
\hline & & & Scottish & Chinese \\
\hline 909706 (P1583) & $\mathrm{T}(0.60)$ & $\mathrm{C}(0.62)$ & $\mathrm{C}(0.61)$ & $\mathrm{T}(0.63$ \\
\hline & & & & - \\
\hline 1763) & $\mathrm{A}(\mathrm{C}$ & ) & A ( & $\mathrm{A}(0$. \\
\hline 7) & $\mathrm{G}($ & & $\mathrm{G}($ & $\mathrm{G}(0.92)$ \\
\hline & $\mathrm{G}(0$ & & $\mathrm{G}(0.8$ & $\mathrm{G}(0.93)$ \\
\hline & & & $\mathrm{C}(0.9$ & $\mathrm{C}(0.80)$ \\
\hline rs2619539 (P1655) & $\mathrm{C}(0 . \mathrm{C}$ & $\mathrm{C}(\mathrm{C}$ & $\mathrm{G}(0.53)$ & $\mathrm{C}(0.6$ \\
\hline rs 3829893 & $\mathrm{G}(0.68)$ & - & - & - \\
\hline rs742106 (P1328) & $\mathrm{T}(0.58)$ & $\mathrm{C}(0.62)$ & - & - \\
\hline
\end{tabular}

${ }^{a}$ The SNP number in the study of Straub et al. (2002a). 
were overlapped, the peak of non-parametric linkage score was on the marker D6S285, 3.5 Mb from DTNBP1. This suggested that DTNBP1 might not be within the candidate region. The single point and haplotype association analyses in this sub-sample were also not significant (data not shown).

Ethnic differences might contribute to our failure to replicate prior studies. The comparison of allele frequencies of the SNPs between our samples, those of Straub et al. (2002a) and Li et al. (2005) was listed in Table 6. The allele frequencies of the SNPs in our Taiwan Chinese sample were similar to those of Han Chinese (Li et al., 2005) and different from those of Irish sample (Straub et al., 2002a) and Scottish sample (Li et al., 2005). However, the risk haplotypes ' $\mathrm{G}-\mathrm{G}$ ' of P1757-P1765 and ' $\mathrm{G}-\mathrm{A}-\mathrm{C}$ ' of P1757-P1765-P1325 reported to have significant association evidence in Li et al. (2005) were not significant in our sample (Chi-square $=0.10, d f=1, p>0.05 ;$ Chi-square $=1.1$, $d f=1, p>0.05$, respectively). The risk haplotype of 'G-T-C-A' of P1655-P1763-P1578-P1583 reported to have significant association evidence in another Han Chinese sample (Tang et al., 2003) were also not significant in our sample (Chi-square $=2.14, d f=1$, $p>0.05$ ). Mutation screening study could not identify any mutation and/or polymorphism in the $5^{\prime}$ promoter region or the protein-coding sequences of DTNBP1 in a Taiwanese Han Chinese sample (Liao and Chen, 2004). These differing results suggest that genetic heterogeneity exists in the susceptibility genes across different ethnic groups.

The powers to detect association for each relative risk of $1.4,1.5$, and 1.6 , were $0.50,0.73$, and 0.89 , respectively, in the additive model. The powers for the same relative risk were $0.52,0.76$, and 0.91 , respectively, in the multiplicative model. These results indicated that the study has enough power to detect the association with the relative risk over 1.6. Therefore, the negative results in our study may not result from inadequate power to detect gene of moderate genetic effects.

Considering the different statistical strategies across studies, we also used the moving window strategy in addition to SNPtagger program to detect all the possible haplotypes with significant association and the results were still not significant. We genotyped only one SNP in the distal genomic region of the gene; therefore, we cannot exclude completely the possibility of association with the distal genomic region of DTNBP1 in our sample.

Another reason for failure to replicate in our sample may be due to a complex pattern of allelic associations that are not sufficiently captured by the SNPs employed in the present study. This is consistent with the observation that different haplotypes from this gene seem to be contributing to different populations (Schwab et al., 2003). Our samples come from families with at least two affected siblings. We failed to replicate the finding that DTNBP1 is particularly involved in schizophrenic cases with a familial genetic loading (Van Den Bogaert et al., 2003).

In summary, we failed to replicate the association evidence between DTNBP1 and schizophrenia and this gene may not play a major role in the etiology of schizophrenia in this Taiwanese family sample.

\section{Acknowledgements}

We gratefully acknowledge the help from the Department of Medical Research in National Taiwan University Hospital and the SNP genotyping work done by the National Genotyping Center (NGC), National Science Council, Taiwan. This study was supported by grants from the National Science Council, Taiwan (NSC91-3112-B-002-011; NSC-92-3112-B-002-019; NSC93-3112-B-002-012; NSC-94-3112-B-002-020); NSC95-3112-B002-011, and the National Health Research Institute, Taiwan (NHRI-90-8825PP; NHRI-EX91, 92, 93, 94-9113PP; NHRI-EX-9511PP and National Institute of Mental Health, USA (IRO1 MH59624-01).

\section{References}

Abecasis, G.R., Cookson, W.O., 2000. GOLD-graphical overview of linkage disequilibrium. Bioinformatics 16 (2), 182-183.

Abecasis, G.R., Cardon, L.R., Cookson, W.O., 2000. A general test of association for quantitative traits in nuclear families. Am. J. Hum. Genet. 66 (1), 279-292.

Andreasen, N., 1983. The Scale for the Assessment of Negative Symptoms (SANS). University of Iowa, Iowa City, IA.

Andreasen, N., 1984. The Scale for the Assessment of Positive Symptoms (SAPS). University of Iowa, Iowa City, IA.

Antonarakis, S.E., Blouin, J.L., Pulver, A.E., Wolyniec, P., Lasseter, V.K., Nestadt, G., Kasch, L., Babb, R., Kazazian, H.H., Dombroski, B., et al., 1995. Schizophrenia susceptibility and chromosome 6p24-22. Nat. Genet. 11 (3), 235-236.

APA, 1994. Diagnostic and Statistical Manual of Mental Disorders, Fourth Edition (DSM-IV). American Psychiatric Association, Washington DC.

Arolt, V., Lencer, R., Nolte, A., Muller-Myhsok, B., Purmann, S., Schurmann, M., Leutelt, J., Pinnow, M., Schwinger, E., 1996. Eye tracking dysfunction is a putative phenotypic susceptibility marker of schizophrenia and maps to a locus on chromosome $6 \mathrm{p}$ in families with multiple occurrence of the disease. Am. J. Med. Genet. 67 (6), 564-579.

Bailer, U., Leisch, F., Meszaros, K., Lenzinger, E., Willinger, U., Strobl, R., Gebhardt, C., Gerhard, E., Fuchs, K., Sieghart, W., Kasper, S., Hornik, K., Aschauer, H.N., 2000. Genome scan for susceptibility loci for schizophrenia. Neuropsychobiology 42 (4), 175-182. 
Bray, N.J., Preece, A., Williams, N.M., Moskvina, V., Buckland, P.R., Owen, M.J., O’Donovan, M.C., 2005. Haplotypes at the dystrobrevin binding protein 1 (DTNBP1) gene locus mediate risk for schizophrenia through reduced DTNBP1 expression. Hum. Mol. Genet. 14 (14), 1947-1954.

Brzustowicz, L.M., Honer, W.G., Chow, E.W., Hogan, J., Hodgkinson, K., Bassett, A.S., 1997. Use of a quantitative trait to map a locus associated with severity of positive symptoms in familial schizophrenia to chromosome 6p. Am. J. Hum. Genet. 61 (6), 1388-1396.

Chen, W.J., Liu, S.K., Chang, C.J., Lien, Y.J., Chang, Y.H., Hwu, H.G., 1998. Sustained attention deficit and schizotypal personality features in nonpsychotic relatives of schizophrenic patients. Am. J. Psychiatry 155 (9), 1214-1220.

Clayton, D., 1999. A generalization of the transmission/disequilibrium test for uncertain-haplotype transmission. Am. J. Hum. Genet. 65 (4), 1170-1177.

De Luca, V., Voineskos, D., Shinkai, T., Wong, G., Kennedy, J.L., 2005. Untranslated region haplotype in dysbindin gene: analysis in schizophrenia. J. Neural Transm. 112 (9), 1263-1267.

DeRosse, P., Funke, B., Burdick, K.E., Lencz, T., Ekholm, J.M., Kane, J.M., Kucherlapati, R., Malhotra, A.K., 2006. Dysbindin genotype and negative symptoms in schizophrenia. Am. J. Psychiatry 163 (3), $532-534$.

Fallin, M.D., Lasseter, V.K., Avramopoulos, D., Nicodemus, K.K., Wolyniec, P.S., McGrath, J.A., Steel, G., Nestadt, G., Liang, K.Y., Huganir, R.L., Valle, D., Pulver, A.E., 2005. Bipolar I disorder and schizophrenia: a 440-single-nucleotide polymorphism screen of 64 candidate genes among Ashkenazi Jewish case-parent trios. Am. J. Hum. Genet. 77 (6), 918-936.

Fanous, A.H., van den Oord, E.J., Riley, B.P., Aggen, S.H., Neale, M.C., O’Neill, F.A., Walsh, D., Kendler, K.S., 2005. Relationship between a high-risk haplotype in the DTNBP1 (dysbindin) gene and clinical features of schizophrenia. Am. J. Psychiatry 162 (10), $1824-1832$.

Funke, B., Finn, C.T., Plocik, A.M., Lake, S., DeRosse, P., Kane, J.M., Kucherlapati, R., Malhotra, A.K., 2004. Association of the DTNBP1 locus with schizophrenia in a US population. Am. J. Hum. Genet. 75 (5), 891-898.

Gornick, M.C., Addington, A.M., Sporn, A., Gogtay, N., Greenstein, D., Lenane, M., Gochman, P., Ordonez, A., Balkissoon, R., Vakkalanka, R., Weinberger, D.R., Rapoport, J.L., Straub, R.E., 2005. Dysbindin (DTNBP1, 6p22.3) is associated with childhoodonset psychosis and endophenotypes measured by the Premorbid Adjustment Scale (PAS). J. Autism Dev. Disord. 35 (6), 831-838.

Hall, D., Gogos, J.A., Karayiorgou, M., 2004. The contribution of three strong candidate schizophrenia susceptibility genes in demographically distinct populations. Genes Brain Behav. 3 (4), 240-248.

Hedrick, P.W., 1987. Gametic disequilibrium measures: proceed with caution. Genetics 117 (2), 331-341.

Holliday, E.G., Handoko, H.Y., James, M.R., McGrath, J.J., Nertney, D.A., Tirupati, S., Thara, R., Levinson, D.F., Hayward, N.K., Mowry, B.J., Nyholt, D.R., 2006. Association study of the dystrobrevin-binding gene with schizophrenia in Australian and Indian samples. Twin Res. Hum. Genet. 9 (4), 531-539.

Hwu, H.G., 1999. In: Hwu, H.G. (Ed.), Psychiatric Diagnostic Assessment. Publication Committee, College of Medicine, National Taiwan University, Taipei. 7-42 pp.

Hwu, H.G., Yeh, E.K., Chang, L.Y., 1989. Prevalence of psychiatric disorders in Taiwan defined by the Chinese Diagnostic Interview Schedule. Acta Psychiatr. Scand. 79 (2), 136-147.
Hwu, H.G., Lin, M.W., Lee, P.C., Lee, S.F., Ou-Yang, W.C., Liu, C.M., 2000. Evaluation of linkage of markers on chromosome 6p with schizophrenia in Taiwanese families. Am. J. Med. Genet. 96 (1), 74-78.

Hwu, H.G., Chen, C.H., Hwang, T.J., Liu, C.M., Cheng, J.J., Lin, S.K., Liu, S.K., Chen, C.H., Chi, Y.Y., Ou-Young, C.W., Lin, H.N., Chen, W.J., 2002. Symptom patterns and subgrouping of schizophrenic patients: significance of negative symptoms assessed on admission. Schizophr. Res. 56 (1-2), 105-119.

Hwu, H.G., Faraone, S.V., Liu, C.M., Chen, W.J., Liu, S.K., Shieh, M.H., Hwang, T.J., Tsuang, M.M., OuYang, W.C., Chen, C.Y., Chen, C.C., Lin, J.J., Chou, F.H., Chueh, C.M., Liu, W.M., Hall, M. H., Tsuang, M.T., 2005. Taiwan schizophrenia linkage study: the field study. Am. J. Med. Genet., B Neuropsychiatr. Genet. 134 (1), $30-36$.

Institute, S., 2002. SAS/Genetics User's Guide. SAS Institute Inc, Cary.

Joo, E.J., Lee, K.Y., Jeong, S.H., Ahn, Y.M., Koo, Y.J., Kim, Y.S., 2006. The dysbindin gene (DTNBP1) and schizophrenia: no support for an association in the Korean population. Neurosci. Lett. 407 (2), 101-106.

Ke, X., Cardon, L.R., 2003. Efficient selective screening of haplotype tag SNPs. Bioinformatics 19 (2), 287-288.

Kirov, G., Ivanov, D., Williams, N.M., Preece, A., Nikolov, I., Milev, R., Koleva, S., Dimitrova, A., Toncheva, D., O’Donovan, M.C., Owen, M.J., 2004. Strong evidence for association between the dystrobrevin binding protein 1 gene (DTNBP1) and schizophrenia in 488 parent-offspring trios from Bulgaria. Biol. Psychiatry 55 (10), 971-975.

Lange, C., DeMeo, D., Silverman, E.K., Weiss, S.T., Laird, N.M., 2004. PBAT: tools for family-based association studies. Am. J. Hum. Genet. 74 (2), 367-369.

Li, T., Zhang, F., Liu, X., Sun, X., Sham, P.C., Crombie, C., Ma, X., Wang, Q., Meng, H., Deng, W., Yates, P., Hu, X., Walker, N., Murray, R.M., St Clair, D., Collier, D.A., 2005. Identifying potential risk haplotypes for schizophrenia at the DTNBP1 locus in Han Chinese and Scottish populations. Mol. Psychiatry 10 (11), $1037-1044$

Liao, H.M., Chen, C.H., 2004. Mutation analysis of the human dystrobrevin-binding protein 1 gene in schizophrenic patients. Schizophr. Res. 71 (1), 185-189.

Matthysse, S., Holzman, P.S., Gusella, J.F., Levy, D.L., Harte, C.B., Jorgensen, A., Moller, L., Parnas, J., 2004. Linkage of eye movement dysfunction to chromosome $6 \mathrm{p}$ in schizophrenia: additional evidence. Am. J. Med. Genet., B Neuropsychiatr. Genet. 128 (1), 30-36.

Maziade, M., Roy, M.A., Rouillard, E., Bissonnette, L., Fournier, J.P., Roy, A., Garneau, Y., Montgrain, N., Potvin, A., Cliche, D., Dion, C., Wallot, H., Fournier, A., Nicole, L., Lavallee, J.C., Merette, C., 2001. A search for specific and common susceptibility loci for schizophrenia and bipolar disorder: a linkage study in 13 target chromosomes. Mol. Psychiatry 6 (6), 684-693.

McGuffin, P., Tandon, K., Corsico, A., 2003. Linkage and association studies of schizophrenia. Curr. Psychiatry Rep. 5 (2), 121-127.

Moises, H.W., Yang, L., Kristbjarnarson, H., Wiese, C., Byerley, W., Macciardi, F., Arolt, V., Blackwood, D., Liu, X., Sjogren, B., et al., 1995. An international two-stage genome-wide search for schizophrenia susceptibility genes. Nat. Genet. 11 (3), 321-324.

Morris, D.W., McGhee, K.A., Schwaiger, S., Scully, P., Quinn, J., Meagher, D., Waddington, J.L., Gill, M., Corvin, A.P., 2003. No evidence for association of the dysbindin gene [DTNBP1] with schizophrenia in an Irish population-based study. Schizophr. Res. $60(2-3), 167-172$. 
Numakawa, T., Yagasaki, Y., Ishimoto, T., Okada, T., Suzuki, T., Iwata, N., Ozaki, N., Taguchi, T., Tatsumi, M., Kamijima, K., Straub, R.E., Weinberger, D.R., Kunugi, H., Hashimoto, R., 2004. Evidence of novel neuronal functions of dysbindin, a susceptibility gene for schizophrenia. Hum. Mol. Genet. 13 (21), 2699-2708.

O'Connell, J.R., Weeks, D.E., 1998. PedCheck: a program for identification of genotype incompatibilities in linkage analysis. Am. J. Hum. Genet. 63 (1), 259-266.

Risch, N., 1990. Linkage strategies for genetically complex traits, I. Multilocus models. Am. J. Hum. Genet. 46 (2), 222-228.

Rodi, C.P., Darnhofer-Patel, B., Stanssens, P., Zabeau, M., van den Boom, D., 2002. A strategy for the rapid discovery of disease markers using the MassARRAY system. Biotech. Suppl. 62-66, $68-69$.

Schwab, S.G., Albus, M., Hallmayer, J., Honig, S., Borrmann, M., Lichtermann, D., Ebstein, R.P., Ackenheil, M., Lerer, B., Risch, N., et al., 1995. Evaluation of a susceptibility gene for schizophrenia on chromosome $6 \mathrm{p}$ by multipoint affected sib-pair linkage analysis. Nat. Genet. 11 (3), 325-327.

Schwab, S.G., Hallmayer, J., Albus, M., Lerer, B., Eckstein, G.N., Borrmann, M., Segman, R.H., Hanses, C., Freymann, J., Yakir, A., Trixler, M., Falkai, P., Rietschel, M., Maier, W., Wildenauer, D.B., 2000. A genome-wide autosomal screen for schizophrenia susceptibility loci in 71 families with affected siblings: support for loci on chromosome 10p and 6. Mol. Psychiatry 5 (6), 638-649.

Schwab, S.G., Knapp, M., Mondabon, S., Hallmayer, J., BorrmannHassenbach, M., Albus, M., Lerer, B., Rietschel, M., Trixler, M., Maier, W., Wildenauer, D.B., 2003. Support for association of schizophrenia with genetic variation in the 6p22.3 gene, dysbindin, in sib-pair families with linkage and in an additional sample of triad families. Am. J. Hum. Genet. 72 (1), 185-190.

Straub, R.E., MacLean, C.J., O’Neill, F.A., Burke, J., Murphy, B., Duke, F., Shinkwin, R., Webb, B.T., Zhang, J., Walsh, D., et al., 1995. A potential vulnerability locus for schizophrenia on chromosome 6p24-22: evidence for genetic heterogeneity. Nat. Genet. 11 (3), 287-293.

Straub, R.E., MacLean, C.J., Walsh, D., Kendler, K.S., 1996. Support for schizophrenia vulnerability loci on chromosomes $6 p$ and $8 p$ from Irish families. Cold Spring Harbor Symp. Quant. Biol. 61, $823-833$

Straub, R.E., Jiang, Y., MacLean, C.J., Ma, Y., Webb, B.T., Myakishev, M.V., Harris-Kerr, C., Wormley, B., Sadek, H., Kadambi, B., Cesare, A.J., Gibberman, A., Wang, X., O’Neill, F.A., Walsh, D., Kendler, K.S., 2002a. Genetic variation in the 6p22.3 gene DTNBP1, the human ortholog of the mouse dysbindin gene, is associated with schizophrenia. Am. J. Hum. Genet. 71 (2), 337-348.

Straub, R.E., MacLean, C.J., Ma, Y., Webb, B.T., Myakishev, M.V., Harris-Kerr, C., Wormley, B., Sadek, H., Kadambi, B., O’Neill, F.A., Walsh, D., Kendler, K.S., 2002b. Genome-wide scans of three independent sets of 90 Irish multiplex schizophrenia families and follow-up of selected regions in all families provides evidence for multiple susceptibility genes. Mol. Psychiatry 7 (6), $542-559$.

Talbot, K., Eidem, W.L., Tinsley, C.L., Benson, M.A., Thompson, E.W., Smith, R.J., Hahn, C.G., Siegel, S.J., Trojanowski, J.Q., Gur, R.E., Blake, D.J., Arnold, S.E., 2004. Dysbindin-1 is reduced in intrinsic, glutamatergic terminals of the hippocampal formation in schizophrenia. J. Clin. Invest. 113 (9), 1353-1363.

Tang, J.X., Zhou, J., Fan, J.B., Li, X.W., Shi, Y.Y., Gu, N.F., Feng, G.Y., Xing, Y.L., Shi, J.G., He, L., 2003. Family-based association study of DTNBP1 in 6p22.3 and schizophrenia. Mol. Psychiatry 8 (8), 717-718.

Terwilliger, J., Ott, J., 1994. Handbook for Human Genetic Linkage. Johns Hopkins University Press, Baltimore.

Tochigi, M., Zhang, X., Ohashi, J., Hibino, H., Otowa, T., Rogers, M., Kato, T., Okazaki, Y., Kato, N., Tokunaga, K., Sasaki, T., 2006. Association study of the dysbindin (DTNBP1) gene in schizophrenia from the Japanese population. Neurosci. Res. 56 (2), $154-158$.

Tost, J., Gut, I.G., 2005. Genotyping single nucleotide polymorphisms by MALDI mass spectrometry in clinical applications. Clin. Biochem. 38 (4), 335-350.

Van Den Bogaert, A., Schumacher, J., Schulze, T.G., Otte, A.C., Ohlraun, S., Kovalenko, S., Becker, T., Freudenberg, J., Jonsson, E.G., Mattila-Evenden, M., Sedvall, G.C., Czerski, P.M., Kapelski, P., Hauser, J., Maier, W., Rietschel, M., Propping, P., Nothen, M.M., Cichon, S., 2003. The DTNBP1 (dysbindin) gene contributes to schizophrenia, depending on family history of the disease. Am. J. Hum. Genet. 73 (6), 1438-1443.

van den Oord, E.J., Sullivan, P.F., Jiang, Y., Walsh, D., O’Neill, F.A., Kendler, K.S., Riley, B.P., 2003. Identification of a high-risk haplotype for the dystrobrevin binding protein 1 (DTNBP1) gene in the Irish study of high-density schizophrenia families. Mol. Psychiatry 8 (5), 499-510.

Wang, S., Sun, C.E., Walczak, C.A., Ziegle, J.S., Kipps, B.R., Goldin, L.R., Diehl, S.R., 1995. Evidence for a susceptibility locus for schizophrenia on chromosome 6pter-p22. Nat. Genet. 10 (1), $41-46$.

Weickert, C.S., Straub, R.E., McClintock, B.W., Matsumoto, M., Hashimoto, R., Hyde, T.M., Herman, M.M., Weinberger, D.R., Kleinman, J.E., 2004. Human dysbindin (DTNBP1) gene expression in normal brain and in schizophrenic prefrontal cortex and midbrain. Arch. Gen. Psychiatry 61 (6), 544-555.

Williams, N.M., Preece, A., Morris, D.W., Spurlock, G., Bray, N.J., Stephens, M., Norton, N., Williams, H., Clement, M., Dwyer, S., Curran, C., Wilkinson, J., Moskvina, V., Waddington, J.L., Gill, M., Corvin, A.P., Zammit, S., Kirov, G., Owen, M.J., O’Donovan, M.C., 2004. Identification in 2 independent samples of a novel schizophrenia risk haplotype of the dystrobrevin binding protein gene (DTNBP1). Arch. Gen. Psychiatry 61 (4), 336-344. 